ARTICLE

Received 1 Feb 2016 | Accepted 5 Apr 2017 | Published 1 Jun 2017

DOl: $10.1038 /$ ncomms15543

OPEN

\title{
Multicentennial record of Labrador Sea primary productivity and sea-ice variability archived in coralline algal barium
}

P. Chan', J. Halfar', W. Adey², S. Hetzinger ${ }^{3}$, T. Zack ${ }^{4}$, G.W.K. Moore ${ }^{5}$, U.G. Wortmann6, B. Williams ${ }^{7}$ \& A. Hou ${ }^{1}$

Accelerated warming and melting of Arctic sea-ice has been associated with significant increases in phytoplankton productivity in recent years. Here, utilizing a multiproxy approach, we reconstruct an annually resolved record of Labrador Sea productivity related to sea-ice variability in Labrador, Canada that extends well into the Little Ice Age (LIA; 1646 AD). Barium-to-calcium ratios $(\mathrm{Ba} / \mathrm{Ca})$ and carbon isotopes $\left(\delta^{13} \mathrm{C}\right)$ measured in long-lived coralline algae demonstrate significant correlations to both observational and proxy records of sea-ice variability, and show persistent patterns of co-variability broadly consistent with the timing and phasing of the Atlantic Multidecadal Oscillation (AMO). Results indicate reduced productivity in the Subarctic Northwest Atlantic associated with AMO cool phases during the LIA, followed by a step-wise increase from 1910 to present levels-unprecedented in the last 363 years. Increasing phytoplankton productivity is expected to fundamentally alter marine ecosystems as warming and freshening is projected to intensify over the coming century.

\footnotetext{
${ }^{1}$ Department of Chemical and Physical Sciences, University of Toronto, 3359 Mississauga Road North, Ontario, Canada L5L 1C6. ${ }^{2}$ Department of Botany, Smithsonian National Museum of Natural History, 1000 Constitution Avenue, NW, Washington, District Of Columbia 20560, USA. ${ }^{3}$ GEOMAR, HelmholtzZentrum für Ozeanforschung Kiel, Wischhofstr. 1-3, 24148 Kiel, Germany. ${ }^{4}$ Department of Earth Sciences, University of Gothenburg, Guldhedsgatan 5A, 40530 Göteborg, Sweden. ${ }^{5}$ Department of Physics, University of Toronto, 60 St George Street, Ontario, Canada M5S 1A7. ${ }^{6}$ Department of Earth Sciences, University of Toronto, 22 Russell Street, Ontario, Canada M5S 3B1. ${ }^{7}$ W.M. Keck Science Department, Claremont McKenna College, Pitzer College, Scripps College, 925 North Mills Avenue, Claremont, California 91711, USA. Correspondence and requests for materials should be addressed to P.C.

(email: phoebetw.chan@utoronto.ca) or to J.H. (email: jochen.halfar@utoronto.ca).
} 
T he Subarctic North Atlantic is one of the most seasonally productive marine environments in the world, accounting for roughly $50 \%$ of global ocean productivity ${ }^{1}$. The seasonal melting of sea-ice in spring results in an increase in incident solar radiation, shoaling of the mixed layer, and release of nutrients and trace elements into the water column, triggering the onset of the spring phytoplankton bloom ${ }^{2}$. Phytoplankton abundance not only influences fisheries production and marine species diversity, but also plays an important role in atmosphereocean carbon exchange, and the export of carbon into the deep $\mathrm{sea}^{3}$. This blooming process is dependent upon physical properties of the surface seawater (for example, temperature, stratification, mixed-layer depth, light levels and nutrient availability) that are directly modified by climatological factors (for example, solar radiation, cloud cover, wind mixing and upwelling) ${ }^{4}$.

Arctic sea-ice thickness and concentration have dropped by $\sim 9 \%$ per decade since 1978 (ref. 5). Concurrent with this sea-ice decline is an increase in rates of phytoplankton productivity, driven by the enhanced transmittance of solar radiation into the surface ocean ${ }^{6-9}$. This ongoing loss in Arctic sea-ice cover has also been associated with an increased export of drift ice and freshwater out of the Arctic Ocean through the Fram Strait, and into the North Atlantic via the East Greenland Current ${ }^{10}$ (Fig. 1a,b). Upon reaching the Davis Strait, the bulk of the transport is diverted westward and combines with the southward flowing polar waters originating from the Nares Strait and Canadian Arctic Archipelago to form the Labrador Current ${ }^{11}$. Since the mid-1960s, large pulses of polar freshwater (as evidenced by negative anomalies in ocean salinities) have been transported into the Nordic and Labrador Seas ${ }^{12}$. Therefore, continued warming of the surface ocean layer is expected to have significant impacts on primary productivity ${ }^{13}$.

Phytoplankton growth in mid-to-high latitude regions is often limited by low light levels due to deep vertical mixing ${ }^{13,14}$. However, continued freshening associated with warming and seaice melt can supply additional buoyancy to the water column, reducing the mixed layer depth and leading to higher levels of productivity 8,14 . This has recently been confirmed by phytoplankton studies in Arctic and Subarctic basins that have revealed earlier timing 9,15 , prolonged duration ${ }^{6,9,16}$ and increased primary productivity 6,17 of the spring phytoplankton bloom. In fact, the most recent estimate indicates a $30 \%$ increase in net primary productivity in the Arctic Ocean between 1998 and 2012 (ref. 9). Enhanced biological productivity can significantly alter patterns of nutrient cycling in the ocean by essentially 'stripping' nutrients from the surface layer ${ }^{18}$, and can also influence the life history and abundance of zooplankton (for example, Calanus finmarchicus) in the North Atlantic ${ }^{19}$; with implications for fishery yields and higher-level trophic interactions ${ }^{16,20,21}$. Thus, ocean warming, driving variations in sea-ice extent, volume and freshwater transport can play an important role in determining the timing, magnitude and duration of the spring bloom. However, difficulties of navigating in remote ice-laden waters and harsh polar climates have often resulted in short and incomplete records of in situ plankton abundance in the Northwestern Labrador Sea ${ }^{22}$. The Arrigo and van Dijken ${ }^{9}$ satellite-derived productivity record ( $\sim 15$-year duration) represents the longest time series of primary productivity associated with changes in Arctic sea-ice cover, allowing for analyses of interannual oceanographic processes and their impacts on phytoplankton production to be made. While this represents a significant step forward in uncovering the driving mechanisms behind currently observed changes in ocean productivity, the relatively short record precludes analyses of long-term climatic variability before the period of satellite observation. Therefore, high-resolution reconstructions of primary productivity are needed, particularly in sparsely sampled regions such as the Northwest Atlantic, in order to place the currently observed productivity increase in the context of long-term climatic variability.

Carbon isotopes extracted from long-lived carbonate marine organisms have been commonly utilized as past recorders of surface water productivity in the North Atlantic ${ }^{23-26}$. However, this method is limited to productivity reconstructions before the second half of the last century due to an overprint by the anthropogenically induced decline of global carbon isotopes resulting from the burning of fossil fuels (Suess effect ${ }^{27}$ ). Alternatively, information of past ocean productivity may be gained through the study of trace nutrient distributions in the water column. Investigations of dissolved barium (Ba) concentrations in the Arctic reveal significant depletions of $\mathrm{Ba}$ in surface seawaters shortly following the spring phytoplankton bloom $^{28,29}$. Barium is a naturally occurring biointermediate element that exhibits nutrient-type behaviour in the open ocean, characterized by depletions in the surface layer and enrichment with depth ${ }^{28,30}$. This pattern has been attributed to the uptake of $\mathrm{Ba}$ in the surface ocean associated with the formation of biological particulate matter, and the subsequent regeneration at depth due to the respiratory breakdown of organic matter ${ }^{31-33}$. Barium commonly behaves as a conservative dissolved tracer, and is incorporated into the carbonate skeleton of calcifying organisms in proportion to ambient seawater concentrations ${ }^{34}$.

In this study, multicentennial records of barium-to-calcium trace element ratios $(\mathrm{Ba} / \mathrm{Ca})$ and carbon isotopic compositions $\left(\delta^{13} \mathrm{C}\right)$ were extracted from two long-lived annually banded specimens of the crustose coralline alga Clathromorphum compactum, as proxies for Labrador Sea primary productivity associated with climate-driven sea-ice variability. On the basis of this $\mathrm{Ba} / \mathrm{Ca}$ proxy record, we examine how long-term climate oscillations driving sea-ice variability in the Subarctic Northwest Atlantic have influenced productivity since the Little Ice Age. Our annually resolved proxy record for surface ocean productivity shows a step-wise increase to levels unmatched over the last 363 years that is likely associated with warming ocean temperatures and sea-ice melt.

\section{Results}

Sample collection. Two living specimens of the alga Clathromorphum compactum were collected: Sample Kil was collected in July 2011 at $15-17 \mathrm{~m}$ water depth, and sample 2013-15-4 in July 2013 at $17 \mathrm{~m}$ water depth via SCUBA off the east coast of Eastern Kingitok Island in Labrador, Canada $\sim 15 \mathrm{~km}$ offshore from central Labrador, Canada $\left(55^{\circ} 26^{\prime} 6.58^{\prime \prime} \mathrm{N}, 59^{\circ} 51^{\prime} 55.57^{\prime \prime} \mathrm{W}\right.$; Fig. 1a,b; for detailed description of sampling sites, see Adey et al. ${ }^{35}$. Additional information about crustose coralline algae can be found in Supplementary Note 1). Sample Kil was analysed for both magnesium-to-calcium $(\mathrm{Mg} / \mathrm{Ca})$ and barium-to-calcium $(\mathrm{Ba} / \mathrm{Ca})$ trace element ratios (363-year record), and specimen 2013-15-4 for annual $\mathrm{Mg} / \mathrm{Ca}$ cycles and carbon isotopic composition $\left(\delta^{13} \mathrm{C}\right.$; 194-year record).

Validation of the algal $\mathrm{Ba} / \mathrm{Ca}$ productivity proxy. Algal $\mathrm{Ba} / \mathrm{Ca}$ ratios were correlated to an algal $\delta^{13} \mathrm{C}$ record (commonly utilized as a measure of surface water productivity ${ }^{27}$ ), to validate the reliability of coralline algal $\mathrm{Ba} / \mathrm{Ca}$ as a proxy for primary productivity. Oceanic $\delta^{13} \mathrm{C}$ values declined steeply throughout the North Atlantic after 1960 due to anthropogenic inputs of isotopically light carbon ${ }^{25}$-which is unrelated to primary productivity. Post $1960 \delta^{13} \mathrm{C}$ data were thus excluded from the comparison and further analysis. Both the annually resolved and 


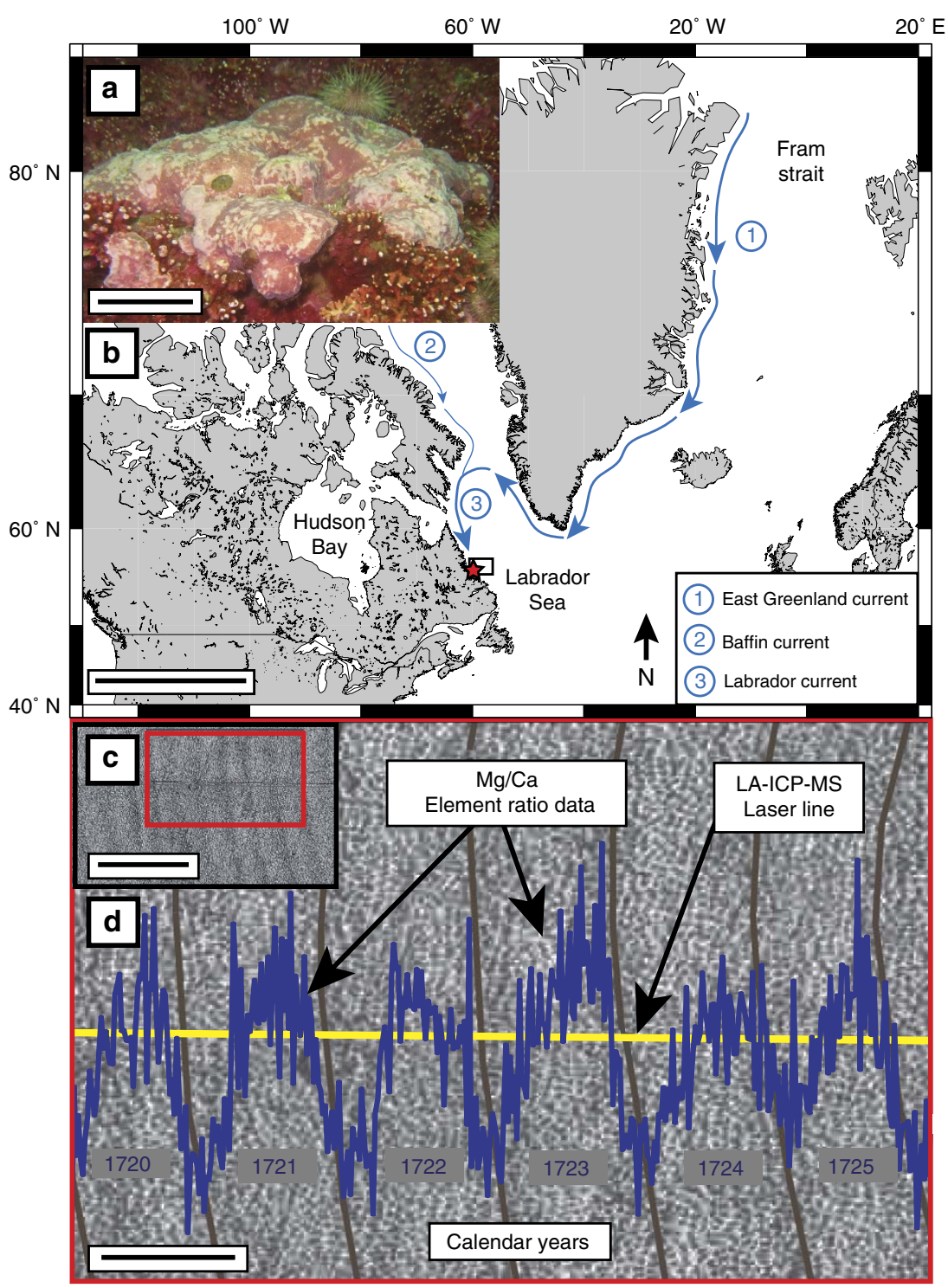

Figure 1 | Crustose coralline alga in the Subarctic North Atlantic. (a) Underwater image of Clathromorphum compactum. Scale bar, $20 \mathrm{~cm}$. (b) Sample collection site off Kingitok Island in Labrador, Canada (red star). Retangular box shows region selected for spatial averaging of SeaWiFS ocean colour data and EN 4.2.0 gridded salinity data (56.0577-58.0133 $\mathrm{N} ; 57.0905-61.0455^{\circ} \mathrm{W}$ ). Arctic sea-ice and freshwater export follow major pathways of flow into the North Atlantic (blue arrows) - (1) East Greenland Current; (2) Baffin Island Current; and combine to form (3) Labrador Current. Scale bar, 2,000 km. Map created using open source software Generic Mapping Tools (GMT; available at: http://gmt.soest.hawaii.edu). (c) Image of cross-sectional polished specimen surface showing annual growth banding. Scale bar, $1 \mathrm{~mm}$. (d) Enlarged image depicts assigned calendar years, growth increment boundaries (grey lines), LA-ICP-MS laser-line transect (yellow line) and $\mathrm{Mg} / \mathrm{Ca}$ trace element ratio data (blue) plotted such that each $\mathrm{Mg} / \mathrm{Ca}$ cycle represents 1 year of growth. Scale bar, $350 \mu \mathrm{m}$.

decadally smoothed algal $\mathrm{Ba} / \mathrm{Ca}$ time series show a close correspondence to the algal $\delta^{13} \mathrm{C}$ record from 1870 to 1960 (annual mean: $r=-0.53, P<0.001, P_{\text {adj }}=0.0038 ; 10$-year mean: $r=-0.89, \quad P_{\text {adj }}=0.003$; Fig. 2a-c). Significance levels were adjusted for loss in degrees of freedom using a lag-1 test that takes into account the temporal autocorrelation of the underlying time series ${ }^{36}\left(P_{\text {adj }}=\right.$ adjusted for loss of degrees of freedom). Minor departures observed between the annually resolved algal $\mathrm{Ba} / \mathrm{Ca}$ and $\delta^{13} \mathrm{C}$ time series may be explained by natural variability within the proxy system, resulting from the records being obtained from two different specimens collected from nearby sites. The high degree of correlation between both the $\mathrm{Ba} /$ $\mathrm{Ca}$ and $\delta^{13} \mathrm{C}$ time series before 1960 indicates that algal $\mathrm{Ba} / \mathrm{Ca}$ ratios at this site can be used as a proxy for productivity that does not suffer from the anthropogenically induced carbon isotope decline. Though it is possible for terrestrial runoff to overprint the barium productivity signal, oceanographic measurements of surface waters taken directly off the coast of Labrador show low barium and high salinity levels resulting from only small quantities of local freshwater input with low barium concentrations $^{37}$. Correlations to gridded salinity data (Met Office Hadley Centre observations data set EN 4.2.0 (ref. 38)) for the region depicted in Fig. $1 \mathrm{~b}\left(56.0577-58.0133^{\circ} \mathrm{N}\right.$; $57.0905-61.0455^{\circ} \mathrm{W}$ ), show no significant relationship to algal $\mathrm{Ba} / \mathrm{Ca}$ between 1900 and 2009 on annual and decadal timescales (annual mean: $r=-0.19, P>0.05, P_{\text {adj }}=0.29 ; 10$-year mean: $r=-0.35, P_{\text {adj }}=0.32$; Fig. 3a-c). This finding is in agreement with measurements of barium in the Baffin-Labrador region surface water, which indicate no significant relationships with sea surface salinity ${ }^{37}$. The sampling site is constantly bathed by the 

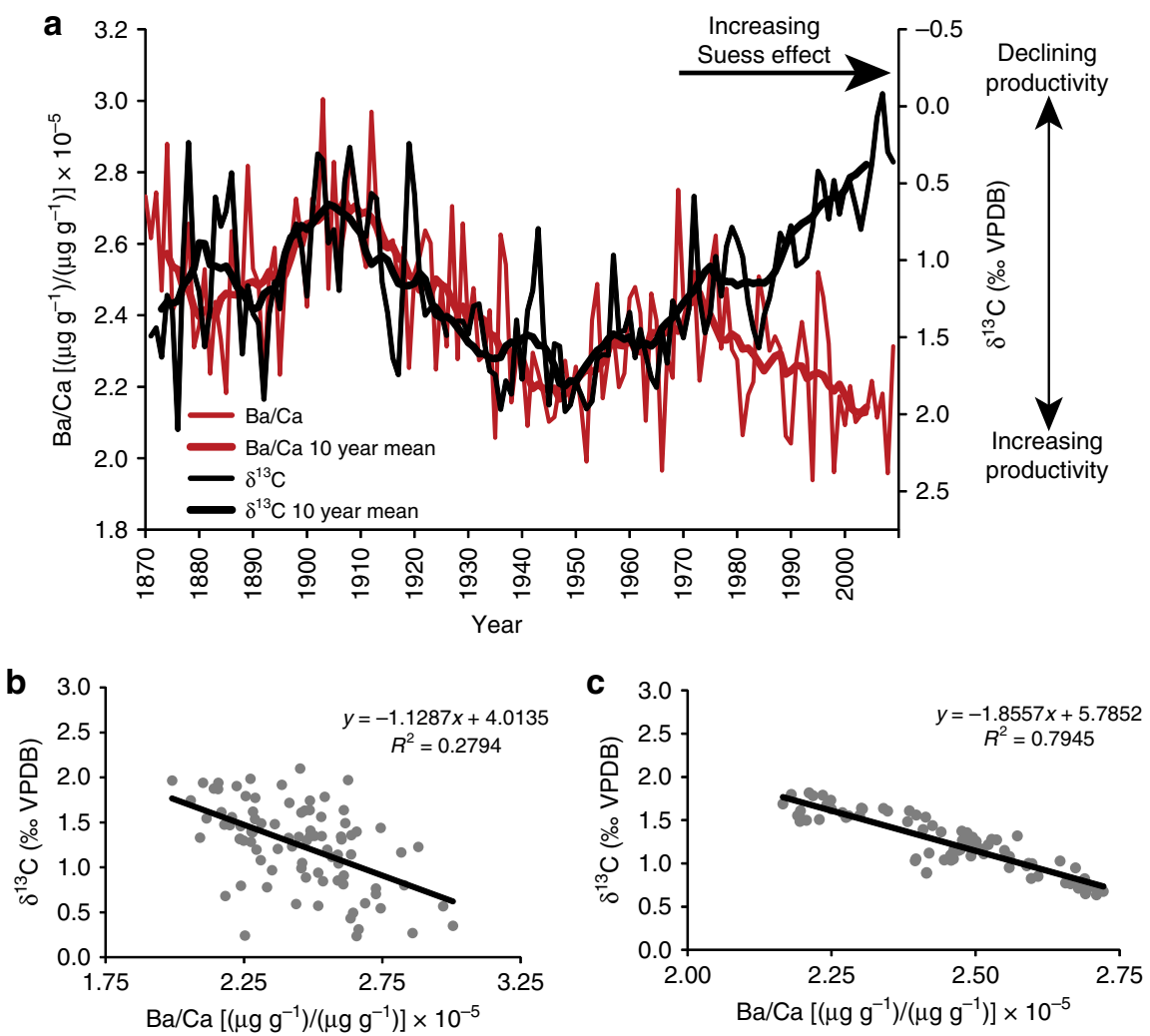

Figure 2 | Relationship between algal $\mathbf{B a} / \mathbf{C a}$ and $\delta^{\mathbf{1 3}} \mathbf{C}$. (a) Annual and 10 -year mean algal $\mathrm{Ba} / \mathrm{C}$ a ratios were derived from sample Kil and $\delta^{13} \mathrm{C}$ values from sample 2013-15-4 (plotted inversely on secondary $x$ axis). The post-1960s departure to negative $\delta^{13} \mathrm{C}$ values is due to the anthropogenic introduction of isotopically light fossil fuels into the biosphere ('Suess Effect'). A $\delta^{13} \mathrm{C}$ decline starting $\sim 1970$ has commonly been observed in marine proxy archives throughout the North Atlantic ${ }^{1}$. Note that outliers defined as \pm four times of interquartile range of raw $\delta^{13} \mathrm{C}$ values were removed from the comparison. Correlations between algal $\mathrm{Ba} / \mathrm{Ca}$ and $\delta^{13} \mathrm{C}$ before the Suess Effect are displayed as scatter plots on (b) annual timescales (1870-1960; $r=-0.53$, $P<0.001 ; P_{\text {adj }}=0.0038$; s.e. of $\mathrm{Ba} / \mathrm{Ca} \pm 0.2 \mathrm{e}^{-5}$ ); and (c) Decadal timescales $\left(1870-1960 ; r=-0.89, P_{\mathrm{adj}}=0.003\right)$. Significance levels were adjusted for loss in degrees of freedom using a lag- 1 test that takes into account the temporal autocorrelation of the underlying time series $\left(P_{\text {adj }}=\right.$ adjusted for loss of degrees of freedom).

inshore branch of the southward-flowing Labrador Current, which, with a flow of 0.8 Sverdrup $^{11}$, dilutes any runoff from the numerous but small river systems along the Labrador coastline. In fact, the Labrador coastline experiences an average runoff of only $600-700 \mathrm{~mm}$ per year ${ }^{39}$. Therefore, the dominant source of barium depletion is likely to be associated with the drawdown of $\mathrm{Ba}$ through intense biological scavenging during primary production, rather than from minor terrestrial freshwater inputs off coastal Labrador.

Algal $\mathbf{B a} / \mathbf{C a}-$ sea-ice relationship. The relationship between the algal $\mathrm{Ba} / \mathrm{Ca}$ productivity proxy and regional sea-ice cover was tested by comparison to monthly Canadian Ice Service (CIS) historical sea-ice cover data to delimit the months of significant $\mathrm{Ba} / \mathrm{Ca}-$ seaice cover relationships 1971-2009 (Fig. 4a). Autocorrelated results indicate that the months August to October of the ice-melt season positively correlate to algal $\mathrm{Ba} / \mathrm{Ca}$ at the $90 \%$ level (grey bars), with the strongest correlations between August and September significant at the $95 \%$ and $99 \%$ levels, respectively (dark grey bars; Fig. 4a). Thus, algal $\mathrm{Ba} / \mathrm{Ca}$ and monthly sea-ice data are most strongly coupled during months where ice-melt is most significant (August to October minimum sea-ice cover; solid black line). This also coincides with months exhibiting the warmest seawater temperatures recorded at depth off Kingitok Island (August to September) ${ }^{35}$. Coralline algae undergo seasonal growth cessation from late winter well into spring (January to May) in the Labrador coastal region. This is due to the presence of sea-ice and thick snow cover which blocks sunlight for photosynthesis-leading to the depletion of overwintering stores of photosynthates with time under the seaice $35,40,41$. Therefore, the algae do not record environmental signals during these months.

Extending the algal $\mathrm{Ba} / \mathrm{Ca}$ - sea-ice comparison to the full length of instrumental observations (since 1971), historical sea-ice coverage for northern Canadian waters was averaged seasonally according to the above established months of significant algal $\mathrm{Ba} / \mathrm{Ca}$-sea-ice relationships (August to October) and correlated to annual coralline algal Ba/Ca ratios (Fig. 4b; 1971 to 2009; $r=0.57, P<0.001$ ). Taking into account the temporal autocorrelation of the underlying time series, correlation was found to be statistically significant at the $99 \%$ confidence level $\left(P_{\mathrm{adj}}=0.013\right)$. Hence, algal $\mathrm{Ba} / \mathrm{Ca}$ ratios are related to late summer Labrador sea-ice coverage since the beginning of the observational data set in 1971. This may result from increased levels of biological scavenging following the seasonal ice breakup (effectively removing $\mathrm{Ba}$ from the surface water column), and reduces the availability of barium for uptake by the coralline algal skeleton. The above relationship is further supported by negative correlations between algal $\mathrm{Ba} / \mathrm{Ca}$ and $\delta^{13} \mathrm{C}$ (Fig. 5a,b), and to spatially averaged chlorophyll $\alpha$ concentrations determined from Sea-Viewing Wide Field-of-View Sensor (SeaWiFS) ocean colour data (Fig. 1b; region in rectangle; 1998 to 2009; $r=-0.78, P=0.0026)$.

The Labrador Sea in the Subarctic Northwest Atlantic receives outflows of Arctic sea-ice and freshwater through the Canadian Arctic Archipelago and the Fram Strait, with the latter serving as the major gateway for polar outflows ${ }^{10}$ (Fig. 1b). The Fram Strait represents the single largest conduit for export of sea-ice out of 

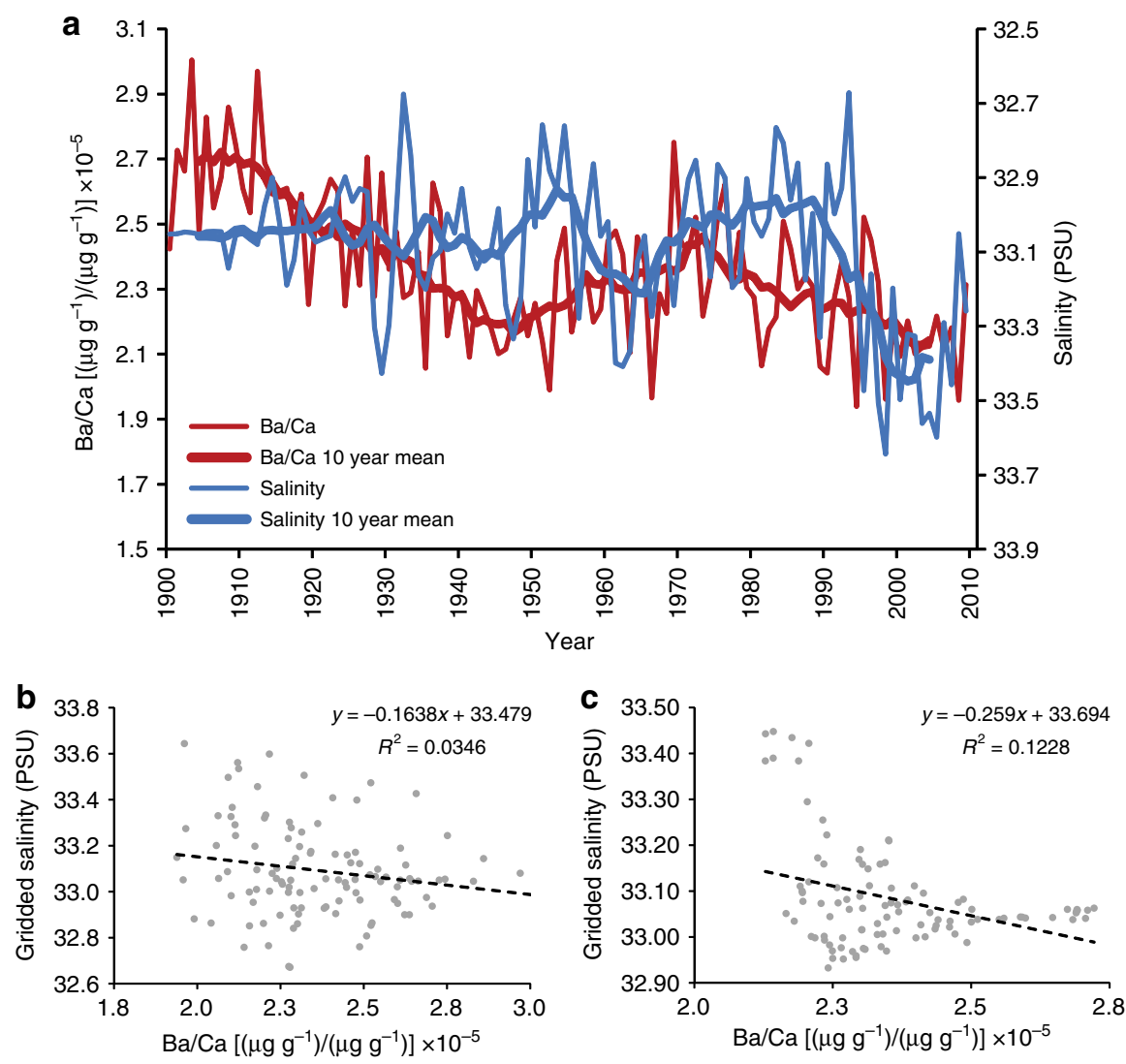

Figure 3 | Algal Ba/Ca versus salinity. (a) Gridded salinity data (Met Office Hadley Centre observations data set EN 4.2.0 ${ }^{2}$ ) for the rectangular region depicted in Fig. $1 \mathrm{~b}\left(56.0577-58.0133^{\circ} \mathrm{N} ; 57.0905-61.0455^{\circ} \mathrm{W}\right)$ show no signficant correlations to algal $\mathrm{Ba} / \mathrm{Ca}$. Algal Ba/Ca versus salinity displayed as scatter plots on (b) annual timescales (1900-2009; $\left.r=-0.19, P>0.05 ; P_{\text {adj }}=0.29\right)$; and (c) Decadal timescales $(1900-2009 ; n=101, r=-0.35$,

$P_{\text {adj }}=0.32$.

the Arctic, accounting for $\sim 26 \%$ of the total sea-ice and freshwater discharge from the Arctic Ocean ${ }^{42}$. Global coupled atmosphere-sea-ice-ocean models demonstrate that during periods of anomalously large ice exports through the Fram Strait, greater volumes of ice are delivered southwards into the East Greenland Current, which subsequently melts and flows into the Labrador Sea as a freshwater/local sea-ice anomaly 1-2 years later ${ }^{43,44}$. These model simulations indicate that following large Fram Strait ice export events, anomalously cold and fresh waters enter into the Labrador Sea, with the ability to reduce salinity, deep convection, and ocean heat release-thus promoting local sea-ice formation ${ }^{43,45}$. To test whether sea-ice export through the Fram Strait influences local sea-ice formation (and hence productivity) in the Labrador Sea, coralline algal $\mathrm{Ba} / \mathrm{Ca}$ was compared to an annually reconstructed record of Fram Strait seaice export from 1,870 to 2,000 (ref. 46). Correlations demonstrate a significant positive relationship between coralline algal $\mathrm{Ba} / \mathrm{Ca}$ ratios and sea-ice export from the Fram Strait with a two-year lag (Fig. 5a,c; 1870-2000; 10-year mean: $r=0.65, P_{\text {adj }}=0.023$ ); the latter accounting for the transit time required for the Fram Strait sea-ice/freshwater signal to propagate into and form sea-ice in the Labrador Sea ${ }^{43}$. These results indicate that Fram Strait sea-ice export influences productivity in the Labrador Sea via local seaice formation, such that a decrease in Fram Strait sea-ice export leads to enhanced productivity, resulting in reduced levels of barium recorded in the coralline algal skeleton, and vice versa.

To examine whether the relationship between the algal multiproxy time series and ice-melt induced primary productivity is sustained over multicentennial timescales, both coralline algal $\mathrm{Ba} / \mathrm{Ca}$ and $\delta^{13} \mathrm{C}$ were compared to a marine sea-ice proxy reconstruction $^{41}$ (Fig. 5a,d). This combined record of $\mathrm{Mg} / \mathrm{Ca}$ trace element ratios with growth increment widths from crustose coralline algae has been used as a joint-proxy for the duration of the open water (ice-free) season associated with increased sea surface temperature (SST) and sunlight reaching the shallow seafloor ${ }^{41}$. The coralline algal $\mathrm{Ba} / \mathrm{Ca}$ record correlates negatively to the combined proxy sea-ice record (Fig. 5a,d; 1646-2009; 10-year mean: $\left.r=-0.75, P_{\mathrm{adj}}<0.001\right)$, such that increases in sea-ice proxy values (related to warming, less sea-ice, and increased light levels) are associated with decreases in algal $\mathrm{Ba}$ / $\mathrm{Ca}$ (resulting from increased primary productivity). In contrast, pre-Suess effect carbon isotopes are positively related to the seaice proxy, and shows positive carbon isotope anomalies (increased productivity) during periods of reduced sea-ice (Fig. 5b,d).

Productivity proxy linked to North Atlantic climate. Historical records of North Atlantic sea-ice variability have recently been shown to covary with phase changes of the Atlantic Multidecadal Oscillation (AMO) index ${ }^{47}$. The AMO is manifested as basinwide sea surface temperature anomalies in low to mid-latitudes $\left(0-60^{\circ} \mathrm{N}\right)$, oscillating between positive and negative phases associated with warm and cool North Atlantic SSTs, respectively, with a periodicity of approximately 60-90 years. This multidecadal pattern of sea-surface temperature variability is thought to be driven by the varying intensity of the Atlantic Meridional Overturning Circulation (AMOC) ${ }^{48}$. Modelling simulations suggest that changes in the AMO and AMOC drive North Atlantic sea-ice extent, such that during periods of high 

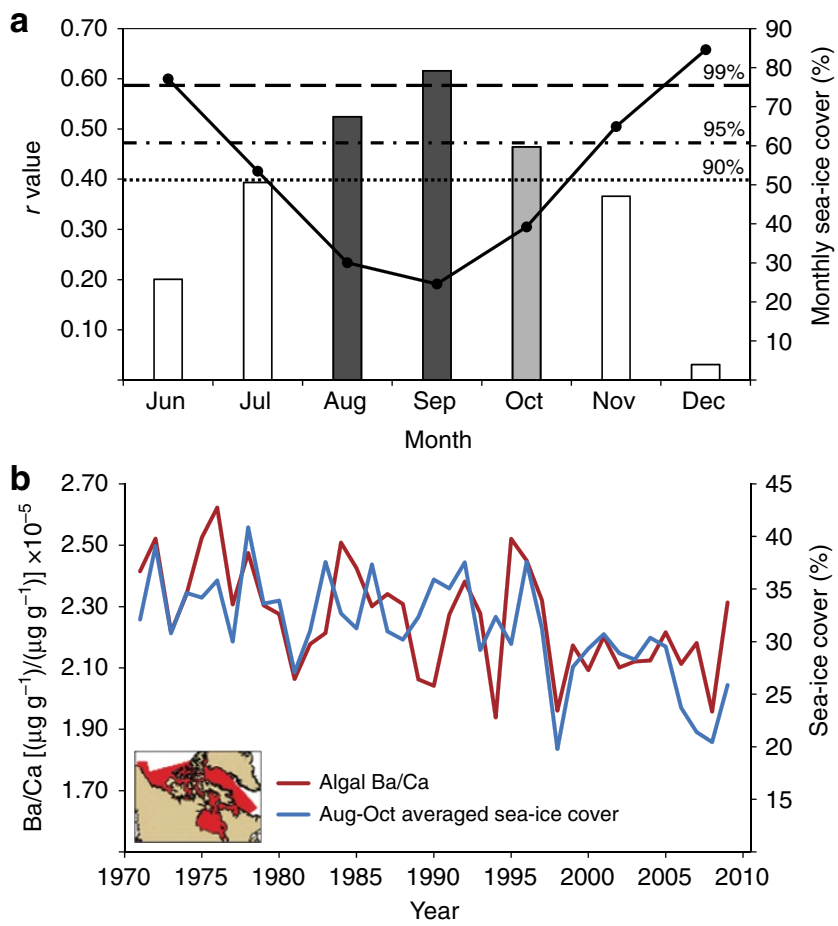

Figure 4 | Relationship between algal $\mathrm{Ba} / \mathrm{Ca}$ and Northern Canadian sea-ice cover. (a) Correlation coefficient ( $r$ value) between annual $\mathrm{Ba} / \mathrm{Ca}$ and monthly averaged sea-ice cover (bars), plotted against monthly averaged sea-ice cover (black line) from 1971 to 2009. Data are shown for months exhibiting significant algal growth (June to December) ${ }^{40,41}$. August to October shows significant correlations to algal Ba/Ca at the $95 \%, 99 \%$ and $90 \%$ levels, respectively (grey bars). White bars indicate insignificant correlations. (b) Annually averaged $\mathrm{Ba} / \mathrm{Ca}$ correlated to seasonally averaged sea-ice cover for the months exhibiting significant sea-ice-algal $\mathrm{Ba} / \mathrm{Ca}$ correlations (1971 to 2009; August to October; $r=0.57, P<0.001$, $\left.P_{\text {adj }}=0.013\right)$ for the region in red (inset).

index values (warm phases), intensification of deep convection leads to a subsequent release of heat that warms surface air and seawater temperatures in the Labrador and Nordic Seas, thus inhibiting the formation of sea-ice $e^{49,50}$. In contrast, periods of low AMO/AMOC index values (cool phases) have been linked to weakening of deep convection, enhanced sea-ice export through the Fram Strait, and an increased presence of sea-ice in the Subarctic North Atlantic ${ }^{46,47,51}$.

Examination of the algal $\mathrm{Ba} / \mathrm{Ca}$ time series reveals long-term multidecadal variability with a characteristic AMO-like frequency as illustrated using a multi-taper power spectrum on the gapcorrected time series (Fig. 6; 1646-2009; approximately 55-60 years significant at the $99 \%$ level). Multidecadal Ba/Ca cyclicities strongly covary with the instrumental AMO index ${ }^{52}$ (Fig. 5a,e; 1900-2009; detrended 10-year mean: $r=-0.83$, $\left.P_{\text {adj }}=0.0028\right)$, such that AMO cool phases (1900-1927 and 1963-1995) are associated with higher $\mathrm{Ba} / \mathrm{Ca}$; and $\mathrm{AMO}$ warm phases (1928-1962 and mid-1990s to present) are associated with lower $\mathrm{Ba} / \mathrm{Ca}$ levels.

On multicentennial timescales, coralline algal $\mathrm{Ba} / \mathrm{Ca}$ continues to demonstrate an inverse relationship with a tree-ring proxybased reconstruction of the AMO index ${ }^{53}$ (Fig. 5a,f; 1646-1990; detrended 10-year mean: $\left.r=-0.55, \quad P_{\text {adj }}=0.0016\right)$. This extended comparison between coralline algal $\mathrm{Ba} / \mathrm{Ca}$ and the proxy-based AMO index reveals additional cycles of depressed algal $\mathrm{Ba} / \mathrm{Ca}$ values that roughly correspond to the AMO warm phases (1670-1710 and 1780-1800), and increases in algal Ba/Ca during AMO cool phases (1710-1735, 1745-1755, 1765-1780 and 1800-1820). Co-variability between the two proxy records suggests that more frequent periods of enhanced algal $\mathrm{Ba} / \mathrm{Ca}$ peaks are associated with AMO cool phases during the Little Ice Age (1550-1850 AD).

\section{Discussion}

Previously, $\mathrm{Ba} / \mathrm{Ca}$ trace element ratios have been used for the reconstruction of coastal runoff, stratification, and/or upwelling depending on the source of barium in surface waters, which in turn is largely determined by the local setting of the sampling region $^{54-57}$. As mentioned in the above, minor contributions of local runoff (characterized by low barium concentrations) are largely overprinted by the high-volume flow of the inshore branch of the Labrador Current. Thus, barium in this study is interpreted as a primary productivity signal. The Labrador shelf is characterized by moderate to high nutrient concentrations throughout most of the year ${ }^{58}$. Strong vertical mixing replenishes the supply of macronutrients to the surface, but reduces solar attenuation-the principal limiting factor on phytoplankton production in this region ${ }^{58}$. While it is possible for ice-melt induced freshening and stratification to limit nutrient upwelling, the consistently positive associations between algal $\mathrm{Ba} /$ $\mathrm{Ca}$ and sea-ice records indicate that the dilution of $\mathrm{Ba}$ does also not play a significant role in driving the variability observed in the algal $\mathrm{Ba} / \mathrm{Ca}$ record. Instead, the positive sea-ice-algal $\mathrm{Ba} / \mathrm{Ca}$ relationship reflects the biological scavenging of barium as a result of enhanced primary productivity related to the melting of sea-ice; in other words, a reduction of sea-ice cover is associated with higher levels of productivity, which in turn decreases barium availability for algal uptake. Increasing productivity has been linked to larger open water areas (providing suitable ice-free habitats for phytoplankton growth) and longer open water seasons (the timing between spring melt and fall freeze-up-which determines the length of the plankton growing season) ${ }^{6}$. Although no records of barium depletions associated with the recently observed increases in Arctic primary productivity currently exist; intensified biological productivity during seasonal phytoplankton blooms (related to increases in solar radiation and melting of sea-ice) have been shown to be capable of severely depleting and essentially 'stripping' barium from the surface seawater ${ }^{28,29}$.

Before 1840 , higher levels of algal $\mathrm{Ba} / \mathrm{Ca}$ in the Labrador Sea coincide with the Little Ice Age (Fig. 5a), corresponding to lower levels of productivity associated with a cooler climate and extensive sea-ice. Between 1870 and 1910 the AMO shifted from a warm to cool phase, followed closely by a dip and subsequent rise in algal $\mathrm{Ba} / \mathrm{Ca}$ that is mirrored by a decline in $\delta^{13} \mathrm{C}$ (Fig. $5 \mathrm{a}, \mathrm{b}, \mathrm{f}$ ). This coincides with an increase in Fram Strait sea-ice export, and more extensive Labrador Sea ice cover as indicated by the sea-ice proxy time series (Fig. 5a,c,d). Multidecadal cyclicity observed in the various sea-ice and productivity records show a general synchrony with phase changes of the AMO; however, there are slight offsets in the peaks of the sea-ice proxy record (Fig. 5d). These apparent differences may be attributable to regional differences between the algal $\mathrm{Ba} / \mathrm{Ca}$ record (obtained from a single location in Labrador, Canada) and the marine paleo sea-ice proxy reconstruction (averaged from different sites between Labrador and northern Baffin Island, Canada).

Based on satellite-derived estimates, ocean primary productivity has increased over the last 15 years. However, our multicentennial algal $\mathrm{Ba} / \mathrm{Ca}$ record displays a step-wise decline since 1910 which suggests that the recent instrumentally observed productivity increase actually began much earlier, in phase with declining sea-ice cover. While similar rates of decline have been 


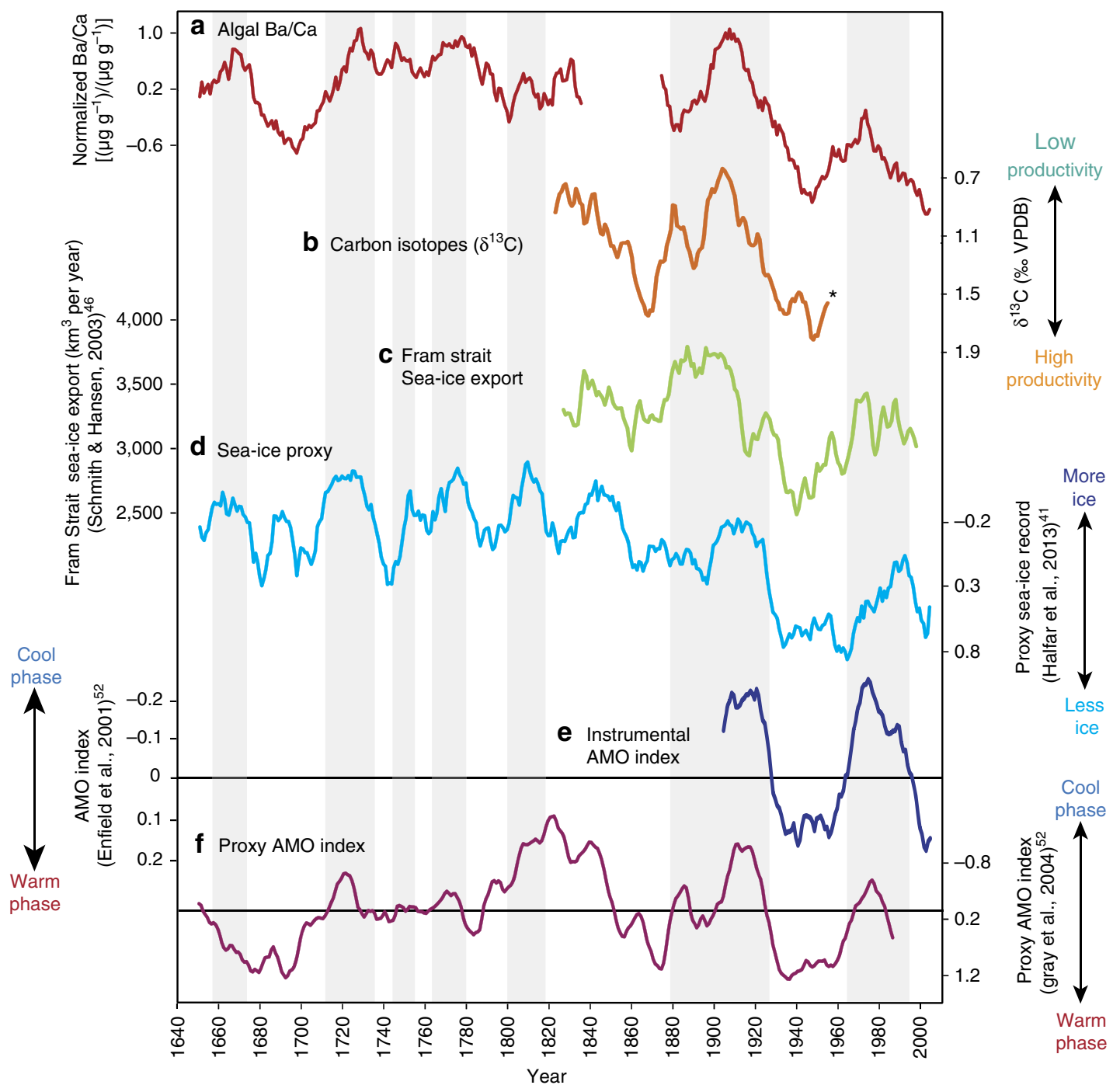

Figure 5 | Coralline algal $\mathrm{Ba} / \mathrm{Ca}$ compared to observational and proxy data. Coloured lines represent 10-year means. (a) Coralline algal $\mathrm{Ba} / \mathrm{Ca}$ was correlated to: (b) Coralline algal $\delta^{13} \mathrm{C}$; (c) Fram Strait sea-ice export ${ }^{46}$; (d) Sea-ice proxy ${ }^{41}$; (e) Instrumental AMO index ${ }^{52}$; and (f) Tree-ring based proxy AMO index ${ }^{53}$. The algal $\delta^{13} \mathrm{C}$ time series in (b) was only plotted until 1960 (asterisk) due to overprinting by anthropogenic input of isotopically light carbon post 1960 (see main text for details). The full annually resolved $\delta^{13} \mathrm{C}$ time series is shown in Fig. 2a. Light grey bars indicate periods of higher Ba/Ca associated with increased sea-ice and cool phases of the Atlantic Multidecadal Oscillation. Note that (d) proxy sea-ice data, (e) instrumental AMO index, and (f) proxy AMO Index are plotted inversely to show increasing sea-ice and cooling.

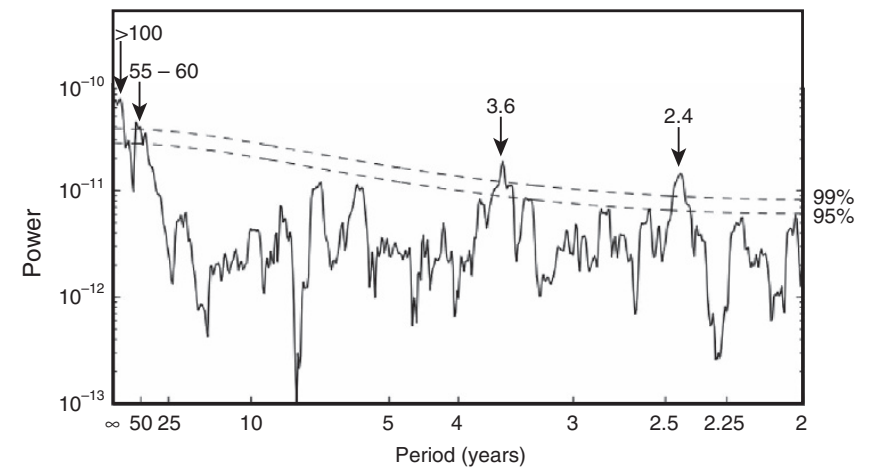

Figure 6 | Multi-taper power spectrum of annually averaged gap-filled $\mathrm{Ba} / \mathrm{Ca}$ time series 1646-2009. Significance estimates based on red-noise AR (1) model shown in Supplementary Fig. 1. Periods (years) of peaks significant at $95 / 99 \%$ level are indicated. observed in earlier parts of the algal $\mathrm{Ba} / \mathrm{Ca}$ record (for example $1670-1700,1910-1950)$, it is only recently that productivity has reached values exceeding those observed in the mid-twentieth century. These values signify the highest levels of productivity since the mid-seventeenth century, which may have resulted from the culmination of a strongly positive AMO state superimposed on the long-term twentieth century warming trend.

The algal $\mathrm{Ba} / \mathrm{Ca}$ record presented here demonstrates that nutrient depletion (driven by intense phytoplankton blooms) is an important process controlling seawater Ba concentrations in highly productive regions such as the Labrador Sea. Synchronous relationships can be observed on multidecadal timescales between algal $\mathrm{Ba} / \mathrm{Ca}$ (as a proxy for ocean productivity) and various instrumentally measured and proxy sea-ice records, all of which are related to phase changes of the AMO. Therefore, the here established climate-driven sea-iceproductivity - algal $\mathrm{Ba} / \mathrm{Ca}$ relationship is likely to be a persistent feature of the Subarctic Northwest Atlantic. 
The multicentennial record of coralline algal $\mathrm{Ba} / \mathrm{Ca}$ ratios indicates that the recently observed productivity increase in the Subarctic Northwest Atlantic has reached levels unprecedented for the last 363 years. Only recently have these values exceeded those in the mid-twentieth century, which may be associated with a strongly positive AMO state further amplified by twentieth century warming. The ongoing loss of sea-ice leading to increasing levels of phytoplankton productivity is predicted to influence nutrient cycling patterns and carbon export to the deep sea, with the potential to fundamentally alter local marine ecosystems and affect fishery yields. This is particularly true for regions such as the Labrador Sea where there are relatively few trophic links in the food web, thus increases in primary productivity are likely to result in wholesale shifts in local species abundance and diversity.

\section{Methods}

Coralline alga preparation and scanning. Algal samples were air-dried and vertically thick-sectioned into $3 \mathrm{~mm}$-thick slabs along the axis of algal growth (perpendicular to growth increments), and sample surfaces were polished to a $3 \mu \mathrm{m}$ finish. High-resolution digital photomosaics (a series of digital images stitched together to form a complete image) of the polished specimen surface were generated at the Department of Chemical and Physical Sciences at the University of Toronto using an Olympus reflected light microscope (VS-BX) attached to an automated sampling stage imaging system equipped with Geo.TS (Olympus Soft Imaging Systems) software (for details, see Hetzinger et al. ${ }^{59}$ ). This microscopic scanning setup enabled detailed viewing with zoom and panning functions using a pyramidal file format. The resulting photomosaics facilitated the establishment of precise age models through the clear identification of annual growth increments, which are delineated by couplets of dark and light bands (Fig. 1c; inset). Calendar years were assigned to each annual growth increment, starting from the year of collection and extending back in time at one year intervals (Fig. 1d). Digitized paths were traced along each annual growth increment boundary using Geo.TS for clear identification of growth layers. Transects for subsequent micromilling and Laser Ablation Inductively Coupled Plasma Mass Spectrometry (LA-ICP-MS) analysis were digitized along the growth axis of both samples also using Geo.TS. The laserline transects were plotted in segments to minimize analytical drift, and allowed for the selection of the most pristine regions of the sample surface for laser analyses (for example avoiding areas of discontinuous growth due to bioerosion or breakage). In addition, laser-lines were overlapped by 3-5 years to ensure reproducibility and continuity of the barium record.

LA-ICP-MS set-up. LA-ICP-MS analysis of magnesium-to-calcium $(\mathrm{Mg} / \mathrm{Ca})$ and barium-to-calcium $(\mathrm{Ba} / \mathrm{Ca})$ trace element ratios were conducted at the Department of Earth Sciences at the University of Gothenburg using an Agilent 7,500a Quadrupole ICP MS attached to a ESI NWR213 laser ablation system equipped with a large format cell. Laser measurements were performed using laser energy densities of ca $7 \mathrm{~J} \mathrm{~cm}^{-2}$, and $0.91 \mathrm{He} \mathrm{min}^{-1}$ as a carrier gas. $2 \mathrm{ml} \mathrm{N}_{2} \min ^{-1}$ were added downstream to the He carrier gas before mixed with $0.71 \mathrm{~min}^{-1}$ Ar. The addition of $\mathrm{N}_{2}$ along with the use of a second rotary vacuum pump lead to an improvement in sensitivity by a factor of two compared to previous measurements (for example Chan et al. ${ }^{57}$ ). Transect lengths were limited to $10,000 \mu \mathrm{m}$ in order to minimize the effect of ICP-MS drift and were analysed at a scan speed of $10 \mu \mathrm{m} \mathrm{s}^{-1}$, with a $60 \mu \mathrm{m}$ spot size and laser frequency of $10 \mathrm{~Hz}$. NIST SRM 610 (US National Institute of Standard and Technology Standard Reference Material) glass reference material was used as an external standard. NIST SRM 610 concentrations used are 81,595 p.p.m. for Ca, 435 p.p.m. for $\mathrm{Mg}$ and 452 p.p.m. for $\mathrm{Ba}$, extracted from the GeoReM database (available from: http://georem.mpchmainz.gwdg.de/, version 04/01/2012). Detection limits were: $M g=0.01$ p.p.m., $\mathrm{Ca}=4$ p.p.m., $\mathrm{Ba}=0.005$ p.p.m. All data are reported as Element/Ca mass ratios $\left(\left(\mu \mathrm{gg}^{-1}\right) /\left(\mu \mathrm{gg}^{-1}\right)\right)$, which can be converted to molar ratios $\left(\mathrm{mol} \mathrm{mol}^{-1}\right)$ by dividing ratios by a conversion divisor $(0.60644 \text { for } \mathrm{Mg} / \mathrm{Ca}, 3.42649 \text { for } \mathrm{Ba} / \mathrm{Ca})^{37}$.

Age model development. Subannually resolved age models were established based on seasonal cyclic variations in $\mathrm{Mg} / \mathrm{Ca}$ element ratios. While LA-ICP-MS derived $\mathrm{Mg} / \mathrm{Ca}$ cycles were available for sample Kil, qualitative $\mathrm{Mg} / \mathrm{Ca}$ cycles were obtained in the W.M. Keck Science Department of Claremont McKenna College, Pitzer College, and Scripps College using a Perkin Elmer 8,300 ICP OES attached to an ESI NWR213 LA system equipped with a large format cell for the purpose of establishing an age model for sample 2013-15-4. According to monthly averages of Extended Reconstructed Sea Surface Temperatures (ERSST v4; 1854-2009 (ref. 60)), the maximum (minimum) $\mathrm{Mg} / \mathrm{Ca}$ values of seasonal cycles were interpreted to correspond to months exhibiting the warmest-August (coolestMarch) temperatures off Kingitok Island, Labrador. Maximum and minimum $\mathrm{Mg} / \mathrm{Ca}$ values were determined by graphically superimposing seasonal $\mathrm{Mg} / \mathrm{Ca}$ cycles onto a photomosaic of the sample surface depicting laser transects, with the maxima of $\mathrm{Mg} / \mathrm{Ca}$ aligned to the central portion of each growth increment, and the minima aligned to growth increment transitions (Fig. 1d). This cross-checking method ensured that each individual $\mathrm{Mg} / \mathrm{Ca}$ cycle was matched with a corresponding annual growth increment in order to avoid possible errors in the age model. Anchor points were assigned beginning with the first $\mathrm{Mg} / \mathrm{Ca}$ minimum (for example March 2010), followed by the subsequent $\mathrm{Mg} / \mathrm{Ca}$ maximum (for example August 2009) and continuing back in time. The algal $\mathrm{Mg} / \mathrm{Ca}$ time series for both samples were then linearly interpolated between these anchor points using AnalySeries software ${ }^{61}$ to obtain an equidistant proxy time series at a resolution of 12 samples per year. $\mathrm{Mg} / \mathrm{Ca}$ cycle based age models were confirmed by radiocarbon dating, where all ages obtained by cycle counting fell within the error of the calibrated radiocarbon age ranges ${ }^{42}$. As sample collection took place in the summer, the final year of algal growth and the outermost layer before collection was incomplete and therefore excluded from the analyses. Last, since algal $\mathrm{Ba} / \mathrm{Ca}$ ratios do not exhibit annual cyclicity, $\mathrm{Mg} / \mathrm{Ca}$ anchor points were transferred to barium laser measurements in order to create the $\mathrm{Ba} / \mathrm{Ca}$ age model.

A 30-year hiatus in the algal Ba/Ca time series is evident from 1840 to 1870 as a result of a gap in LA-ICP-MS measurements. LA-ICP-MS transects were taken parallel to previously measured electron microprobe lines extending across the entire lifespan of the algal specimen ${ }^{41}$. LA-ICP-MS analysis was conducted in order to obtain $\mathrm{Ba} / \mathrm{Ca}$ records from the algal specimen as microprobe analyses were limited to measuring only $\mathrm{Mg} / \mathrm{Ca}$ ratios. Through electron microprobe analyses, a geochemically altered region of the specimen was discovered (as indicated by significantly depressed amplitudes of $\mathrm{Mg} / \mathrm{Ca}$ cycles), and was therefore avoided for subsequent laser analyses. However, detailed microscopic inspection of the sample surface within the altered region displayed clear growth banding, which enabled precise calendar dating of the period where no laser measurements were taken. These dates were further confirmed using radiocarbon ages, which indicated that there was no significant hiatus in the altered region ${ }^{41}$. The age model for algal $\mathrm{Ba} /$ $\mathrm{Ca}$ was then developed accordingly to account for the years of missing data in the altered region. A detrended $\mathrm{Ba} / \mathrm{Ca}$ record was used for correlations to the proxy AMO index. Before detrending, a Singular Spectral Analysis $\left(\mathrm{SSA}^{62}\right.$ ) was performed in order to fill the gap in laser data collection. This gap-filling technique ensured that the linear trend in the gap-filled time series was not significantly different than the unfilled time series (significant at the $99 \%$ level; Supplementary Fig. 1).

Carbon isotope analysis. Material for isotope analysis was obtained from specimen 2013-15-4 by micromilling of 247 samples parallel to growth increments using a milling path spacing of $180 \mu \mathrm{m}$ (for details on micromilling technique applied to coralline algae see Williams et al. ${ }^{63}$ ). About $200 \mu \mathrm{g}$ of material was introduced in $5 \mathrm{ml}$ vacutainers, and all ambient atmosphere was flushed with a helium stream. Five to ten drops of phosphoric acid was added to the sample vial and heated at $70^{\circ} \mathrm{C}$ for $1 \mathrm{~h}$ before analysis. The evolving $\mathrm{CO}_{2}$ was analysed for $\delta^{13} \mathrm{C}$ using a Thermo Finnigan Gas Bench II coupled to a Thermo Finnigan Mat 253 isotope ratio monitoring mass spectrometre in continuous flow mode. The system was calibrated using the following standards $\mathrm{CaCO}_{3}$ Merck, IAEA-CO-8, IAEA-CO-1 and NBS 19. Analytical reproducibility was determined from repeated measurements at 1 -sigma $= \pm 0.07 \%$ for $\delta^{13} \mathrm{C}$. Samples were obtained for the last 194 years of growth of specimen 2013-15-4 according to an age model established from annual $\mathrm{Mg} / \mathrm{Ca}$ cycles. Based on this age model $\delta^{13} \mathrm{C}$ values from the 247 samples measured were downsampled to annual resolution (194 years) using AnalySeries software ${ }^{61}$

Observational and proxy data sets. Historical ice coverage data from northern Canada was obtained from the Canadian Ice Service, Environment Canada (https:// www.ec.gc.ca/glaces-ice/). Percentage ice cover data in the northern Canadian waters region was obtained from IceGraph Tool 2.0 for the months exhibiting the minimum sea-ice cover (August to October) from 1971 to 2009 (ref. 64). The data from the IceGraph Tool 2.0 are derived from weekly regional ice charts from predefined regions (based on the compilation analysis of satellite imagery, weather and oceanographic information, and observations from ships and aircrafts), and is calculated by multiplying the percentage of sea area in a specified region that is covered by ice, by the concentration of ice. Chlorophyll $\alpha$ concentrations $\left(\mathrm{mg} \mathrm{m}^{-3}\right)$ for the years 1998-2009 were determined from Level 3 (monthly, $9 \mathrm{~km}$ resolution) Sea-Viewing Wide Field-of-View Sensor (SeaWiFS) ocean colour data obtained using the Giovanni online data system, developed and maintained by the NASA Goddard Earth Sciences Data and Information Services Center (GES DISC; http://gdata1.sci.gsfc.nasa.gov/daac-bin/G3/gui.cgi?instance_id=ocean_month). Fram Strait sea-ice export data were obtained from a reconstruction based on historical observations of multiyear ice called 'Storis' from ship logbooks and ice charts off the southwestern coast of Greenland ${ }^{46}$. Since summer months contain the most data coverage, summer storis observations extracted from historical records were used to create the storis extent index ${ }^{46}$ (May to July; 1820-2000). Although the Fram Strait sea-ice export record dates back to the early 1800s, decadal-scale relationships to algal $\mathrm{Ba} / \mathrm{Ca}$ (based on 10-year running means) were only examined for the period from 1870 to 2009 due to the gap in LA-ICP-MS analysis of the algal $\mathrm{Ba} / \mathrm{Ca}$ record. Similarly, correlation coefficients between $\delta^{13} \mathrm{C}$ and $\mathrm{Ba} / \mathrm{Ca}$ ratios were only determined for the post-gap period until 1960, when 
the Suess effect resulted in a significant anthropogenic overprinting of the $\delta^{13} \mathrm{C}$ signal.

Data availability. All relevant data are available upon request from the authors. Requests for materials should be addressed to Phoebe Chan (phoebetw.chan@utoronto.ca).

\section{References}

1. Tilstone, G. H., Miller, P. I., Brewin, R. J. W. \& Priede, I. G. Enhancement of primary production in the North Atlantic outside of the spring bloom, identified by remote sensing of ocean colour and temperature. Remote Sens. Environ. 146, 77-86 (2014).

2. Frajka-Williams, E. \& Rhines, P. B. Physical controls and interannual variability of the Labrador Sea spring phytoplankton bloom in distinct regions. Deep Sea Res. Part I Oceanogr. Res. Pap 57, 541-552 (2010).

3. Alkire, M. B. et al. Estimates of net community production and export using high-resolution, Lagrangian measurements of $\mathrm{O}_{2}, \mathrm{NO}_{3}-$, and POC through the evolution of a spring diatom bloom in the North Atlantic. Deep Sea Res. Part I Oceanogr. Res. Pap 64, 157-174 (2012).

4. Behrenfeld, M. J. Climate-mediated dance of the plankton. Nat. Clim. Change 4, 880-887 (2014)

5. Comiso, J. C. Large decadal decline of the Arctic multiyear ice cover. J. Clim. 25, 1176-1193 (2012).

6. Arrigo, K. R., van Dijken, G. \& Pabi, S. Impact of a shrinking Arctic ice cover on marine primary production. Geophys. Res. Lett. 35, L19603 (2008).

7. Arrigo, K. R. \& van Dijken, G. L. Secular trends in Arctic Ocean net primary production. J. Geophys. Res. Ocean. 116, C09011 (2011).

8. Arrigo, K. R. et al. Massive phytoplankton blooms under Arctic sea ice. Science 336, 1408 (2012).

9. Arrigo, K. R. \& van Dijken, G. L. Continued increases in Arctic Ocean primary production. Prog. Oceanogr. 136, 60-70 (2015).

10. Serreze, M. C., Holland, M. M. \& Stroeve, J. Perspectives on the Arctic's shrinking sea-ice cover. Science 315, 1533-1536 (2007).

11. Lazier, J. R. N. \& Wright, D. G. Annual velocity variations in the Labrador current. J. Phys. Oceanogr. 23, 659-678 (1993).

12. Curry, R., Dickson, B. \& Yashayaev, I. A change in the freshwater balance of the Atlantic Ocean over the past four decades. Nature 426, 826-829 (2003).

13. Sarmiento, J. L. et al. Response of ocean ecosystems to climate warming. Glob. Biogeochem. Cycle 18, GB3003 (2004).

14. Doney, S. C. Oceanography: Plankton in a warmer world. Nature 444, 695-696 (2006).

15. Harrison, W. G. et al. Phytoplankton production and growth regulation in the Subarctic North Atlantic: A comparative study of the Labrador Sea-Labrador/ Newfoundland shelves and Barents/Norwegian/Greenland seas and shelves. Prog. Oceanogr. 114, 26-45 (2013).

16. Drinkwater, K. \& Pepin, P. Comparison of climate forcing on the marine ecosystems of the Northeast and Northwest Atlantic: a synthesis of the NORCAN Project Preface. Prog. Oceanogr. 114, 3-10 (2013).

17. Brown, Z. W. \& Arrigo, K. R. Contrasting trends in sea ice and primary production in the Bering Sea and Arctic Ocean. ICES J. Mar. Sci. 69, 1180-1193 (2012).

18. Guay, C. K. H., McLaughlin, F. A. \& Yamamoto-Kawai, M. Differentiating fluvial components of upper Canada Basin waters on the basis of measurements of dissolved barium combined with other physical and chemical tracers. J. Geophys. Res. Oceans 114, C00A09 (2009).

19. Head, E. J. H. et al. On the ecology of Calanus finmarchicus in the subarctic North Atlantic: A comparison of population dynamics and environmental conditions in areas of the Labrador Sea-Labrador/Newfoundland Shelf and Norwegian Sea Atlantic and coastal waters. Prog. Oceanogr. 114, 46-63 (2013).

20. Wassmann, P. Arctic marine ecosystems in an era of rapid climate change. Prog. Oceanogr. 90, 1-17 (2011).

21. Brander, K. M. Global fish production and climate change. Proc. Natl Acad. Sci. USA 104, 19709-19714 (2007).

22. Richardson, A. J. et al. Using continuous plankton recorder data. Prog. Oceanogr. 68, 27-74 (2006).

23. Druffel, E. R. M. \& Benavides, L. M. Input of excess $\mathrm{CO}_{2}$ to the surface ocean based on $13 \mathrm{C} / 12 \mathrm{C}$ ratios in a banded Jamaican sclerosponge. Nature 321, 58-61 (1986).

24. Böhm, F. et al. Carbon isotope records from extant Caribbean and south Pacific sponges: Evolution of delta C-13 in surface water DIC. Earth. Planet Sci. Lett. 139, 291-303 (1996).

25. Swart, P. K. et al. The 13C Suess effect in scleractinian corals mirror changes in the anthropogenic $\mathrm{CO}_{2}$ inventory of the surface oceans. Geophys. Res. Lett. 37, L05604 (2010).

26. Grottoli, A. G. \& Eakin, C. M. A review of modern coral delta O-18 and Delta C-14 proxy records. Earth Sci. Rev. 81, 67-91 (2007).
27. Broecker, W. S. a. \& Peng, T. H. Tracers in the Sea (Lamont-Doherty Earth Observatory, 1982).

28. Falkner, K., Macdonald, R. W., Carmack, E. C. \& Weingartner, T. The Polar Oceans and Their Role in Shaping the Global Environment (American Geophysical Unionp 63-76, 1994).

29. Guay, C. K. \& Falkner, K. Barium as a tracer of Arctic halocline and river waters. Deep Sea Res. Part II Top. Stud. Oceanogr. 44, 1543-1569 (1997).

30. Chan, L. H., Drummond, D., Edmond, J. M. \& Grant, B. On the barium data from the Atlantic GEOSECS expedition. Deep Sea Res. 24, 613-649 (1977).

31. Bishop, J. K. B. The barite-opal-organic carbon association in oceanic particulate matter. Nature 332, 341-343 (1988).

32. Dehairs, F., Chesselet, R. \& Jedwab, J. Discrete suspended particles of barite and the barium cycle in the open ocean. Earth. Planet. Sci. Lett. 49, 528-550 (1980).

33. Dymond, J., Suess, E. \& Lyle, M. Barium in the deep-sea sediment: A geochemical proxy for paleoproductivity. Paleoceanography 7, 163-181 (1992).

34. Lea, D. \& Boyle, E. Barium content of benthic foraminifera controlled by bottom-water composition. Nature 338, 751-753 (1989).

35. Adey, W. et al. Subarctic rhodolith beds promote longevity of crustose coralline algal buildups and their climate archiving potential. Palaios 30, 281-293 (2015).

36. Santer, B. D. et al. Statistical significance of trends and trend differences in layer-average atmospheric temperature time series. J. Geophys. Res. Atmos. 105, 7337-7356 (2000).

37. Yamamoto-Kawai, M., Carmack, E. C., McLaughlin, F. A. \& Falkner, K. K. Oxygen isotope ratio, barium and salinity in waters around the North American coast from the Pacific to the Atlantic: Implications for freshwater sources to the Arctic throughflow. J. Mar. Res. 68, 97-117 (2010).

38. Good, S. A., Martin, M. J. \& Rayner, N. A. EN4: Quality controlled ocean temperature and salinity profiles and monthly objective analyses with uncertainty estimates. J. Geophys. Res. Oceans 118, 6704-6716 (2013).

39. Rollings, K. The hydrology of Labrador. Department of Environment Water Resources Division Report, Government of Newfoundland and Labrador, 106 p. Available at: http://www.env.gov.nl.ca/env/waterres/reports/hydrology_lab/ hydrol_lab_chap2.pdf (1997).

40. Adey, W. H., Halfar, J. \& Williams, B. The coralline genus Clathromorphum foslie emend. adey: biological, physiological, and ecological factors controlling carbonate production in an arctic-subarctic climate archive. Smithsonian contributions to the marine sciences 40, 1-41 (2013).

41. Halfar, J. et al. Arctic sea-ice decline archived by multicentury annualresolution record from crustose coralline algal proxy. Proc. Natl Acad. Sci. USA 110, 19737-19741 (2013)

42. Serreze, M. C. et al. The large-scale freshwater cycle of the Arctic. J. Geophys. Res. Oceans 111, 19 (2006).

43. Koenigk, T., Mikolajewicz, U., Haak, H. \& Jungclaus, J. Variability of Fram Strait sea ice export: causes, impacts and feedbacks in a coupled climate model. Clim. Dyn. 26, 17-34 (2006).

44. Haak, H., Jungclaus, J., Mikolajewicz, U. \& Latif, M. Formation and propagation of great salinity anomalies. Geophys. Res. Lett. 30, 4 (2003).

45. Hakkinen, S. A simulation of thermohaline effects of a great salinity anomaly J. Clim. 12, 1781-1795 (1999).

46. Schmith, T. \& Hansen, C. Fram Strait ice export during the nineteenth and twentieth centuries reconstructed from a multiyear sea ice index from southwestern Greenland. J. Clim. 16, 2782-2791 (2003).

47. Miles, M. W. et al. A signal of persistent Atlantic multidecadal variability in Arctic sea ice. Geophys. Res. Lett. 41, 2013 GL058084 (2014).

48. Delworth, T. L. \& Mann, M. E. Observed and simulated multidecadal variability in the Northern Hemisphere. Clim. Dyn. 16, 661-676 (2000).

49. Day, J. J., Hargreaves, J. C., Annan, J. D. \& Abe-Ouchi, A. Sources of multidecadal variability in Arctic sea ice extent. Environ. Res. Lett. 7, 034011 (2012).

50. Mahajan, S., Zhang, R. \& Delworth, T. L. Impact of the Atlantic Meridional Overturning Circulation (AMOC) on Arctic surface air temperature and sea ice variability. J. Clim. 24, 6573-6581 (2011).

51. Dima, M. \& Lohmann, G. A hemispheric mechanism for the Atlantic multidecadal oscillation. J. Clim. 20, 2706-2719 (2007).

52. Enfield, D. B., Mestas-Nunez, A. M. \& Trimble, P. J. The Atlantic multidecadal oscillation and its relation to rainfall and river flows in the continental US. Geophys. Res. Lett. 28, 2077-2080 (2001).

53. Gray, S. T., Graumlich, L. J., Betancourt, J. L. \& Pederson, G. T. A tree-ring based reconstruction of the Atlantic Multidecadal Oscillation since 1567A.D. Geophys. Res. Lett. 31, L12205 (2004).

54. Lea, D. W., Shen, G. T. \& Boyle, E. A. Coralline barium records temporal variability in equatorial Pacific upwelling. Nature 340, 373-376 (1989).

55. LaVigne, M., Grottoli, A. G., Palardy, J. E. \& Sherrell, R. M. Multi-colony calibrations of coral $\mathrm{Ba} / \mathrm{Ca}$ with a contemporaneous in situ seawater barium record. Geochim. Cosmochim. Acta 179, 203-216 (2016).

56. Sinclair, D. J. \& McCulloch, M. T. Corals record low mobile barium concentrations in the Burdekin River during the 1974 flood: evidence for limited Ba supply to rivers? Paleogeogr. Paleoclimatol. Paleoecol. 214, 155-174 (2004). 
57. Chan, P. et al. Freshening of the Alaska Coastal Current recorded by coralline algal Ba/Ca ratios. J. Geophys. Res.-Biogeogr. 116, G01032 (2011).

58. Harrison, W. G. \& Li, W. K. Phytoplankton growth and regulation in the Labrador Sea: Light and nutrient limitation. J. Northw. Atlant. Fish. Sci. 39, 71-82 (2007).

59. Hetzinger, S. et al. High-resolution analysis of trace elements in crustose coralline algae from the North Atlantic and North Pacific by laser ablation ICPMS. Paleogeogr. Paleoclimatol. Paleoecol. 302, 81-94 (2011).

60. Huang, B. et al. Extended reconstructed sea surface temperature version 4 (ERSST.v4). Part I: Upgrades and intercomparisons. J. Clim. 28, 911-930 (2014).

61. Paillard, D., Labeyrie, L. \& Yiou, P. Macintosh program performs time-series analysis. Eos Trans. Am. Geophys. Union 77, 379-379 (1996).

62. Ghil, M. et al. Advanced spectral methods for climatic time series. Rev. Geophys. 40, 3.1-3.41 (2002).

63. Williams, B. et al. Twentieth century $\boldsymbol{\delta}^{13} \mathrm{C}$ variability in surface water dissolved inorganic carbon recorded by coralline algae in the northern North Pacific Ocean and the Bering Sea. Biogeosciences 8, 165-174 (2011).

64. Tivy, A. et al. Trends and variability in summer sea ice cover in the Canadian Arctic based on the Canadian Ice Service digital archive, 1960-2008 and 1968-2008. J. Geophys. Res. Oceans 116, C03007 (2011).

\section{Acknowledgements}

We thank Thew Suskiewicz for assisting with algal collections and Anne de Vernal for stimulating discussions. We acknowledge funding from the Natural Sciences and Engineering Research Council of Canada to J.H. and P.C. and the Geological Society of

America to P.C.

\section{Author contributions}

P.C. analysed and interpreted the data, and wrote the manuscript with J.H. who conceived and supervised this research project. W.A. collected algal specimens, and provided background on coralline algal ecology. S.H. aided in interpretation of the results and provided statistical guidance for this project. T.Z. conducted LA-ICP-MS analyses. G.W.K.M. performed the Singular Spectral Analysis (SSA) and multi-taper power spectrum on the time series. U.G.W. and A.H. analysed and interpreted carbon isotope data. B.W. conducted LA-ICP-OES analyses, and all coauthors provided feedback on the manuscript.

\section{Additional information}

Supplementary Information accompanies this paper at http://www.nature.com/ naturecommunications

Competing interests: The authors declare no competing financial interests.

Reprints and permission information is available online at http://npg.nature.com/ reprintsandpermissions/

How to cite this article: Chan, P. et al. Multicentennial record of Labrador Sea primary productivity and sea-ice variability archived in coralline algal barium. Nat. Commun. 8, 15543 doi: $10.1038 /$ ncomms15543 (2017).

Publisher's note: Springer Nature remains neutral with regard to jurisdictional claims in published maps and institutional affiliations.

(c) (i) This work is licensed under a Creative Commons Attribution 4.0 International License. The images or other third party material in this article are included in the article's Creative Commons license, unless indicated otherwise in the credit line; if the material is not included under the Creative Commons license, users will need to obtain permission from the license holder to reproduce the material. To view a copy of this license, visit http://creativecommons.org/licenses/by/4.0/

(C) The Author(s) 2017 